\title{
Gyökér Róbert
}

\section{VILÁGOK KÖZÖTT \\ $A$ fordítás nehézségei}

\section{DOI 10.35402/kek.2019.3.6}

\begin{abstract}
Absztrakt
Lehetséges vajon a teljes megértés? Létrejöhet egy olyan fordítás, amely az idegen kultúra maradéktalan olvasatát nyújtja? Vagy minden vállalkozásunk, amely egy számunkra idegen életvilágból származó tapasztalat fordítására vállalkozik, eleve kudarcra van ítélve? Whorf számára minden individuum a saját kultúrája által közvetített mintázatok kényszerítő erejének van alávetve, így senki sem alkothat hiteles képet egy idegen életvilágról. Davidson ezzel szemben azt vallja, hogy az érzéki tapasztalatban minden adott, ami a sikeres fordítás előfeltétele. De vajon helyes-e végletekben gondolkodnunk? Nem kellene-e inkább engedményeket tennünk és a fordítás szélsőséges elméletei generálta jelentés helyett az átmeneteknek, a jelentés fokozatainak több figyelmet szentelnünk? A whorfi hipotézis a fordítás kudarcának, a davidsoni elmélet a teljes megértés vágyképének paradoxonát hordozza magában. Tanulmányomban a két elmélet bírálatára vállalkozom. Érvelésemet a terepmunkám során gyűjtött tapasztalatokkal igyekszem alátámasztani, amelyet az urbánus sámánság női ágát gondozó közösség körében szereztem.
\end{abstract}

\section{Abstract}

Between wor(l)ds. Difficulties in translation

Is it possible to have a full understanding? Can such a translation be realized that is able to return the full spectrum of a culturally alien society? Or our efforts are inevitably doomed to failure? Whorf believes that each individual is subject to his or her own culture and is unable to create an authentic picture of another society. Davidson on the contrary says that everything is given in the empiric experience that is required to provide a successful translation. Is it proper, though, to think in extremes? Shouldn't we make concessions in the translation process and instead of trying to reach a full understanding pay attention to the various levels of meanings? Whorf's hypothesis leads to the paradox that translation is a hopeless endeavor. Davidson's theory creates the illusion that by assuming general agreement on beliefs a full interpretation can be reached. In this paper, I will address both theories. As a conclusion, I will try to outline a third position based on an ecological perspective. In order to support my ideas, I present some empirical data drawn from my case study that was conducted between the members of a community that follows the female line of urban shamanism.

\section{Kudarcos paradoxon?}

Minden találkozás egy idegen életvilággal való szembesülés. Egy hermeneutikai viszony kezdete, amely értelmezésre, saját világképünk, értékrendünk újragondolására, valamint az idegenség érzésének feloldására sarkall. Legyen szó akár egy másik kultúráról, ahová utazásaink során vetődünk, akár a saját kultúránkon belüli szubkultúráról vagy kisebbségről, amelyekkel mindennapjaink során kerülünk kapcsolatba. A hermeneutikai folyamatot azonban szüntelenül beárnyékolja a teljes megértés illúziója, illetve a fordítás szükségszerű kudarcának a félelme. Felvetődik a kérdés, hogy lehetséges-e egyáltalán a teljes megértés, létrejöhet-e egy olyan fordítás, amely az idegen kultúra maradéktalan olvasatát nyújtja, vagy minden vállalkozásunk, amely egy számunkra idegen életvilágból származó tapasztalat fordítására vállalkozik, eleve kudarcra van ítélve?

A dilemma feloldására eltérő válaszok születtek. Whorf számára minden individuum a saját kultúrája által közvetített mintázatok, interpretációs technikák kényszerítő erejének van alávetve, így senki sem alkothat hiteles képet egy idegen életvilágról. Már a környezeti jelenségek észlelésében és feldolgozásában is alapvető eltérések mutatkoznak. Megértés csak akkor következhet be, ha a megfigyelők hasonló nyelvi háttérrel rendelkeznek, mondjuk ugyanahhoz a nyelvcsaládhoz tartoznak (1956:214). Davidson elfogadhatatlannak tartja a kulturális relativizmus nézeteit. Meglátása, hogy az érzéki tapasztalatban minden adott, ami a sikeres 
fordítás előfeltétele. És mivel a különböző kultúrák mindegyike többé-kevésbé ugyanazt a tárgyi világot, ugyanazt az univerzumot szervezi egésszé, ezért a teljes megértésnek sem lehet akadálya (1974:15).

De vajon helyes-e végletekben gondolkodnunk? Nem kellene-e inkább engedményeket tennünk és a fordítás szélsőséges elméletei generálta jelentés helyett az átmeneteknek, a jelentés fokozatainak, tehát minden olyan olvasatnak több figyelmet szentelnünk, amely kívül esik a „szentesített” interpretációkon? A whorfi hipotézis a fordítás kudarcának, a davidsoni elmélet a teljes megértés vágyképének paradoxonát hordozza magában. Tanulmányomban a két elmélet bírálatára vállalkozom. Írásom első részében az érzékelésnek a jelentés-elóállításban betöltött szerepét, az értelmezés eredményeként megszülető jelentés igazságértékét vizsgálom, ahogy az a racionalista és az empirista szellemi hagyományban megjelenik. A második részben a fordítás természetét és érvényességi körét, valamint az ezzel kapcsolatos nézeteket tekintem át. Végül kísérletet teszek egy alternatív, ökológiai alapokon nyugvó értelmezési stratégia felvázolására. Érvelésemet a terepmunkám során gyüjtött tapasztalatokkal igyekszem alátámasztani, amelyet az urbánus sámánság női ágát gondozó közösség körében szereztem. Îrásomban a fordítás és értelmezés szavakat azonos értelemben használom, függetlenül attól a körülménytől, hogy valamely tartalom interpretációja különböző nyelvek között, vagy az adott nyelvi közegen belül valósul-e meg.

\section{Az érzékelésről}

A racionalizmus és empirizmus közötti vita alapvetően episztemológiai természetű vita, amely az érzéki tapasztalatnak a tudáselőállításban betöltött szerepét vizsgálja. A kérdés, ami eldöntésre vár, hogy az érzéki tapasztalat milyen mértékben tekinthető a tudás forrásának. A racionalizmus szerint ismereteink jelentős része az érzéki tapasztalattól függetlenül létrejött, a priori természetű tudás, amely vagy már eleve velünk született, egyfajta isteni teremtő aktus által belénk oltott, vagy pedig intuíció útján megszerzett bizonyosság. Az empirizmus meggyőződése ezzel szemben, hogy ismereteink végső forrása az érzéki tapasztalat. Általános magyarázóelvek tehát nem léteznek, az emberi tudat csak később, az érzékelést követően alakítja át a benyomásokat összetettebb gondolatokká.

\section{A tapasztalaton túl - a racionalista világkép}

A tudás a priori természetébe vetett hit számos negatív következménnyel jár Winch szerint. Idegen kultúrák vizsgálatakor ugyanis a kutatók gyakran arra kényszerülnek, hogy az eseményeket illuzórikusként tüntessék fel, a jelenségek értelmezése helyett pedig a téveszmék fennmaradásának okait vizsgálják, csak hogy megfeleljenek a racionalitás eszme követelményeinek, és saját olvasóközönségük általános elvárásainak (1964:307). A gondolkodási rendszerek azonban nem rangsorolhatóak. Az oksági kapcsolaton nyugvó tudományos megértés nem tekinthető felsőbbrendűnek más gondolkodási rendszerekkel, világnézetekkel szemben. A racionalisták által alkalmazott intuíció és dedukció elláthat ugyan bennünket általános érvényű igazságokkal, amelyek a tudományos gondolkodás, a formális logika vagy a matematika területén eredményesen alkalmazhatóak, de az így nyert tudás nem a külső valóságról szerzett tudás, hanem pusztán a fogalmaink közötti kapcsolatra vonatkozó ismeret. Egyedi esetekből általános érvényü fogalmakra következtetni elhibázott gondolat Winch meglátása szerint. Ez ugyanis azt jelentené, hogy bizonyítottnak tételezzük azt, ami bizonyítandó, valóságosnak fogadjuk el azt, ami pusztán az egyedi esetekben fellelhető (1988:31). További probléma forrása, hogy az oksági elven nyugvó magyarázat miközben az ész, az értelem felsőbbrendűségét hirdeti, az eseményeket pedig a logikai következtetés és a szükségszerűség magyarázóelvének rendeli alá, gyakorlatilag egy függetlenül létező valóságot feltételez. $\mathrm{Ez}$ az objektív valóság képezi az alapját a tudományos fogalmak müködésének és szolgál referenciapontként más kultúrák vizsgálatakor is. Amennyiben egy hit, egy gondolkodásmód nem felel meg a tudományos gondolkodás szabta kritériumoknak, akkor az az objektív valóság megragadására sem lehet képes és az általa közvetített világkép sem lehet más, mint egy irreális valóság leképeződése. A racionális és irracionális jelenségek megkülönböztetése azonban csak a természettudományok determinisztikus világlátásán nevelkedett nyugati gondolkodásmód sajátja. $\mathrm{Az}$ irracionalitás vádja nem a primitív népek valóságfelfogásának cáfolata, hanem a racionalizmus önnön negációja. Ha az intuíció nem más, mint a fogalmaink közötti kapcsolódási mód egy különös esete, akkor a prelogikus valóságfelfogás sem lehet más, mint a fogalmak kapcsolódási módjának egy alternatív formája. A természeti népek ugyanúgy intuitív módon jutnak el bizonyos felismerésekhez, 
mint a racionalisták, csak eltérő fogalmi rendszerekkel dolgoznak.

Winch a tudományos gondolkodás jellegéből adódó ellentmondást Evans-Pritchard Boszorkányság, jóslás és mágia az Azandék között címü művének vizsgálatán keresztül szemlélteti. Winch szerint fontos különbséget tennünk az azandék társadalmi életét alapvetően meghatározó mágia, valamint a saját kultúránk által vallott mágiafelfogás között. Hogy megértsük a fekete mise lényegét, először ismernünk kell a keresztény egyház miserendjét, mint helyes rítust. Ahhoz azonban, hogy megértsük az azande mágia lényegét, ki kell lépnünk saját kultúránk közegéből, magunk mögött hagyva régi beidegződéseinket, és alá kell merülnünk egy számunkra teljesen idegen kultúra közegébe. Saját kultúránk határain belül maradva a mágia és a boszorkányság megítélése olyan társadalmi kontextuson belül alakul, amely - különösen a kereszténység térhódítása óta - támadóan lép fel a boszorkányság intézményével szemben és az általa folytatott gyakorlatokat a keresztény vallás tanításaival szemben tematizálja. Ebben az összefüggésben a mágia és a boszorkányság a romlottság, az eltévelyedés megtestesítője, és mint irracionális cselekedet elvetendő. A mágia intézményét a saját szociokulturális közegén belül vizsgálva azonban más következtetésre jutunk. A mágia a társadalmi integráció egyik meghatározó eleme az azandéknál. A jós alapvető feladata a természetfeletti erők működésének feltárása. Bár ennek az eljárásnak számos módja létezik, a jósok által megélt revelációk nem állíthatóak párhuzamba sem az általunk vallott „empirikus igazolás” kritériumával, sem pedig a tudományos gondolkodás hipotézisalkotói gyakorlatával. A társadalmi koherenciát biztosító szabályok működése nem ítélhető meg a formális logika általános érvényü törvényei alapján, érvel Winch. Egy idő után ugyanis elérünk egy olyan pontot, ahonnan többé már nem vagyunk képesek meghatározni, hogy mi koherens és mi nem, anélkül, hogy ne kérdőjeleznénk meg magának a vizsgálati pozíciónknak a hitelességét. Az azandék boszorkánysággal kapcsolatos rítusai sokkal szélesebb társadalmi kontextusba ágyazódnak, mint ahogy az a formális logika szabályai alapján elvárható lenne. Nemcsak a termés biztosításának gyakorlati szempontjából meghatározóak, de alapvető a jelentőségük a társadalmi kapcsolatok tekintetében is. Az azande mágia nem pusztán technika, nem egyszerűen egy fogalmi rendszer alkotóelemei közötti viszony formális magyarázata, hanem egyfajta válaszkeresés, amely az emberi élet értelmét igyekszik megragadni. Ebből adódóan a termés, amelynek bőségét a rítusok hivatottak biztosítani, sem egyszerű fogyasztási cikk, hanem egy egész életmód leképeződése. Jelentéstartalmában a társakhoz való viszony, a jó és a rossz közötti választás dilemmája egyaránt kifejeződésre jut (1964:310-315).

A racionalisták szerint az igazságnak létezik egy univerzális, kontextustól független kritériuma, amely mindenki számára egyaránt hozzáférhető. A kultúráknak ez a lényegi összetevője olyan állításokban összegződik, amelyek már a tapasztalás elemi szintjén megmutatkoznak és azonnal felismerhetőek minden racionálisan gondolkodó egyén számára. Létezésük előfeltétele nemcsak a megértésnek, de a sikeres fordításnak is. A fordítás aktusa azonban korántsem a legfontosabb szegmense a megértésnek, ahogy arra több kutató is figyelmeztet. A nyelvi jelentés elsajátítása folyamat-jelleget mutat, amelynek első állomása a gyermekkor. A megértés tehát sokkal inkább a tanulás, a hagyományátadás eredményeként kialakuló beállítódás, amelynek során gyakorlati, mindig az adott szociokulturális helyzethez igazodó megfontolások érvényesülnek, mintsem egyfajta fordítói gyakorlat eredményeként megszülető jelentés. A helyes jelentés elsajátítása kontrollált folyamat, amely a felnőttek folyamatos jelenléte, szüntelen korrekciója mellett valósul meg (Barnes - Bloor 1982:35-38).

További érv a racionalizmus védelmezői részéről, hogy a logikai következtetéseknek van egy egyszerü formája, amelyet mindenki ésszerűnek fogad el. Ez a következtetési szabály a modus ponens sémájában összegződik. A modus ponens egy olyan következtetési eljárás, amely az állítás előtagja és utótagja közötti logikai viszonyt vizsgálja és az előtag fennállásából, érvényességéből arra a következtetésre jut, hogy a vizsgált állítás utótagja is helyes. Bár az állítás a formális logika keretei között maradva igaznak bizonyulhat, a logika határait átlépve azonban már nem feltétlenül alkalmazható. A logikai sémák a premisszák és a konklúzió közötti formális kapcsolatot vizsgálják, és megelégszenek azzal, ha a következtetések teljesítik az igazság kritériumát. A premisszák valóságtartalma a formális logika szempontjából lényegtelen (Winch 1964:308). A jelentés azonban nem logikai sémák kényszerítő erejének engedelmeskedő zárt rendszer, amely univerzális érvényességgel bír. A hitek, világnézetek és gondolkodásmódok lokális természetűek. Hogy megértsük őket, alá kell merülnünk az adott életvilág közegébe. Az antropológus számára valamely jelenség értelmezésének kiindulópontja sohasem a 
jelenség a maga „objektivitásában”, ahogy az a tudományos gondolkodás számára adott, ahogy az értelem bevált magyarázóelvei szerint „nyilvánvaló és egyértelmü", hanem mindig a szociokulturális valóság sajátos adottságai által meghatározott közeg. Így válhat egy vadászó-gyüjtögető életmódot folytató népcsoport mindennapi tevékenysége mitikus tartalommal telített cselekedetté. A cree törzs tagjai szerint például a vadászat nem az állattal szemben elkövetett kegyetlenkedés, ahogyan az a nyugati ember gondolkodásmódjában megjelenik, hanem a természet által kínált nemes áldozat elfogadása. A vadászat során maga a rénszarvas az, amely szándékosan felajánlja magát a vadásznak, az iránta érzett jóindulata, szeretete jeléül. A cree törzs világképén belül a vadászat fogalmát további képek gazdagítják: az állat üldözése egy fiatal nő elcsábításával, meggyilkolása pedig a szexuális aktussal állítható párhuzamba. Az elejtett vad a maga testi mivoltában nem egyszerűen zsákmány, hanem felajánlás, elejtése nem gyilkosság, hanem az újjászületés záloga. A jelenség értelmezésének kiindulópontja tehát nem a vadászat a maga brutalitásában, hanem a vadász és az állat találkozásának közvetlen élménye, amely a cree kozmológia által forgalmazott képek közegébe ágyazódik (Ingold 2000:13-14).

A társadalmi jelenségek vizsgálatakor mindig komplex állításokból indulunk ki, amelyek igazságértéke egy olyan összefüggésrendszerbe ágyazódik, amely nem választható el az adott kultúra többi szegmensétől. A kulturális jelenségek kölcsönös függőségi viszonyban állnak egymással, szerteágazó jelentések szövevényes hálóját alkotva. A jelentésháló elemeinek státusza, tartalmának megítélése pedig eltéréseket mutat a társadalmi nem, a társadalmi idő, az életkor, a tabuk és tilalmak, vagy éppen a hatalmi viszonyok függvényében. Könnyen előfordulhat, hogy ugyanazokból a premisszákból kiindulva egymással teljesen ellentétes következtetésekre jutunk valamely kulturális jelenség vizsgálatakor. De ennek ellenkezője is igaz lehet: hasonló kulturális jegyek egymástól függetlenül is kialakulhatnak. Ez a körülmény különösen szemléletes módon jut kifejeződésre a tárgyi kultúra elemeinek, például a maszkoknak a használata során. Egy maszk szolgálhat arra, hogy viselője megtévessze vele az ártó szellemeket, de lehet kommemoratív jellege is. A yorubáknál a maszk gyakran tölt be közösségi szerepet a különféle beavatási szertartások állandó kísérőjeként. Maszkokat hordhatnak ugyanakkor színházi előadások során is (Boas 2006:141). A jelenség a társadalom szerveződését meghatározó normák kapcsán is kimutatható. A magyar paraszti társadalmon belül elfogadott, egyenesen elvárt volt az a nemi szerepekhez és életkorhoz köthető normaszegés, hogy a legények loptak az otthoni terményből a zsebpénz kiegészítése végett. A verekedés, a legények érezhető jelenlétének a megnyilvánulása, szintén pozitív megítélés alá esett (Jávor 1989). Ugyanezek a viselkedésmódok azonban egy kicsit időben és térben elmozdulva, a magyar falu világa helyett a főváros kontextusában vizsgálva, már sokkal súlyosabb elbírálás alá eshetnek. Bár a társadalmi idő mint változó minden kultúra általános alkotóeleme, az időszemléletben, az időkezelési stratégiákban mutatkozó különbségek szintén egymástól gyökeresen eltérő gazdálkodási formákat, és társadalmi berendezkedést eredményezhetnek. Ha a prekapitalista gazdálkodási módot vizsgáljuk, azt tapasztaljuk, hogy az idő a modern ember felfogásától teljesen eltérő jelentéssel bír. Az algériai parasztoknál a jövő Isten kockajátéka, amibe halandók nem avatkozhatnak bele, és elvárásokat sem fogalmazhatnak meg vele kapcsolatban. Ennek következtében számos gazdasági cselekvés jelentése is módosul, összehasonlítva azt a tőkés gazdaság felfogásmódjával. A tartalékképzés bár gazdasági aktusnak számít, nem az előrelátás, vagy a tervezés része, hanem szokások által meghatározott tevékenység. Olyan rituális előírás, amely a háztartás bőségét hivatott szavatolni. Mivel mezőgazdasági termelésen alapuló gazdaságukban a termelési ciklus rövid, a parasztok ezért nem választják külön munkájukat annak jövőbeni eredményétől, a terméstől. A munkaidőt szintén együtt kezelik a termésidővel. A tőkés termelési mód ezzel szemben jóval átfogóbb, működéséhez az absztrakt idő megalkotása is szükséges. Az elvont időben azonban a gazdasági folyamatok átfogó szemléletének, társadalmi beágyazottságának helyére a részfolyamatok racionális kalkulációja lép. A hitelnyújtás gyakorlata idegen fogalom az algériai parasztság körében. Az írott szerződés a maga szankcióival és meghatározott jövőbeli követeléseivel teljesen értelmezhetetlen számukra. Nem is beszélve a kamatról, amely gyakorlatilag az idő kiszámíthatóságának a megtestesülése. A tőkés hitelnyújtó ezzel szemben objektív bizonyosságot keres. Bevezeti a hitelképesség fogalmát, amelyhez idő szabta korlátokat rendel. Az algériai paraszti világban a jövő megtervezése az isteni nagylelkűségnek szabna határt, és negatív következményekkel járna (Bourdieu 1990).

A következtetés tehát mindig túllép az adott szabály határain, ahogyan azt Lewis Carroll tör- 
ténete Akhillésről és a teknősről is szemléletesen példázza. Carroll kiemeli, hogy minden dedukció igazolása egy előzetes dedukciót előfeltételez, amely körkörös, véget nem érő láncolatot hoz létre egészen addig a pontig jutva, ahol a premisszákat többé már nem lehet pontosan felfejteni. Minél jobban elmosódik állításunk kiindulópontja, annál inkább megkérdőjeleződik logikai következtetésünk igazságtartalma is (Barnes és Bloor 1982:40-43). A körkörösség problematikáját a racionalisták azzal próbálták feloldani, hogy a logikai jelek formális aspektusát emelték ki. A. N. Prior azonban megcáfolta törekvéseiket. Prior érvelésében egy egyszerű nyelvi elem, a kötőszó szerepét használja igazolásként. Meglátása, hogy bármely következtetés kizárólag az „és” szó jelentéséből adódóan igaz, amelynek igazságtartalmát a nyelvben betöltött mellérendelő szerepe biztosítja. Hogy a nyelvi jelek önkényes karakterét bizonyítsa, Prior bevezet egy teljesen új kötőszót (tonk), amelynek jelentése nem tisztázott. Mivel az új szövegkörnyezetben a kötőszó jelentése kimerül a nyelvtani szabályok által meghatározott funkcióban, ezért lehetővé válik, hogy egy analitikai értelemben érvényes következtetés, de annak akár ellentettje is, levezethető legyen bármilyen más következtetésből (Prior 1960:38-39). Prior bizonyításában a szabály lép elő elsődleges szervező erővé, háttérbe szorítva minden egyéb más nyelvi és kulturális tényezőt. Egy pusztán formális logikai szabályok által vezérelt világban azonban a jelentések, és azok igazságtartalma, kulturális meghatározottsága érvényét veszti. A premisszák és következtetések tetszőlegesen felcserélhetőek, akár hamis premisszák és konklúziók is összekapcsolhatóak anélkül, hogy a következtetések integritása sérülne. A szociokulturális valóságban azonban a jelentések és a szabályok kölcsönösen feltételezik egymást. Szabályok kizárólagos alkalmazása még nem igazolja a világról alkotott nézeteink érvényességét, ahogyan azt a formális logika állításai megkövetelnék, ugyanis a szabályokat a világról alkotott nézeteink alapján fogalmazzuk meg.

Az oksági magyarázat helyett a véletlen is kultúraszervező erővé léphet elő. Az olyan mágikus gyakorlatok, mint amilyen például a jóslás, túlmutatnak az oksági magyarázat bizonyosságán és fontos szabályozó szerepet tölthetnek be egy törzs életében. A Naskapik jövendölésében a rénszarvas lapockacsontja különösen kitüntetett szerepet játszik. A gondosan előkészített csontot a naskapik a tűz fölé tartják és az így keletkező repedéseket és égésnyomokat értelmezik. Az egyik alapvető kér- dés, amelyre a naskapik választ várnak, hogy a vadászok merre induljanak a préda elejtéséért. Mivel nem kontrollálják a helyzetet, azaz a foltok, repedések képződését, a végső döntés ezért nem egyéni választás eredménye. A jövendölés gyakorlata szabálytalanságot iktat a naskapik vadászati szokásaiba, amely megóvja az állatokat a túlvadászat ellen. A jóslásnak ugyanakkor a naskapik számára is túlélési értéke van: a törzs tagjai ezáltal kerülik el azt, hogy saját vadászati szokásaik áldozatává váljanak. A jóslás egyfajta véletlenszerűséget biztosító eszköz, amely kiküszöböli az emberi választás kiszámíthatósága okozta negatív következményeket (Moore 1957:69-74).

\section{A közvetlen tapasztalat - az empirista világkép}

$\mathrm{Az}$ empirizmus álláspontja szerint ismereteink érzéki tapasztalaton alapuló, a posteriori ismeretek. Ugyanakkor az emberi tudat nem egyszerüen csak passzív befogadója, de aktív formálója is az érzéki benyomásoknak. Fogalmaink az emberi elme belső reflexiós folyamatainak eredményeként megszülető mentális tartalmak (Locke 1999:86-88). A tapasztalás, a külső környezet felől érkező impressziók közvetlensége tehát megelőzi a fogalomképződés folyamatát. Gondolataink csak másodlagos, származtatott lecsapódásai az érzékek által elénk tárt valóságnak.

Hol a határa azonban ennek a magánminőségü szubjektivitásban adott tapasztalásnak? Milyen szerepet játszanak a közösség által képviselt értékek, hagyományok, a társadalom által közvetített viselkedésminták, értelmezési stratégiák ismereteink kialakításában? Az empirista megközelítés az érzékelés folyamatának szubjektív aspektusát emeli ki, annak ellenére, hogy az egyén társadalmi produktum, aki sohasem a külvilágtól elzártan, hanem az őt körülvevő szociokulturális valóság szerves részeként szemléli a világot. A szubjektum univerzumába zárt empirikus tapasztalat szociokulturális értelemben nem mond semmit sem a világ jelenségeiről azon túl, hogy a percepció szintjén beazonosítja azokat. A világ azonban nem pusztán a percepcióban adott érzéki tapasztalás lenyomata, hanem olyan jelentéssel telített közeg, amelyben értékrendek, hagyományok, viselkedésmódok tükröződnek. Az a körülmény, hogy a biológiailag egységes emberi faj szociokulturális önmegvalósítás tekintetében rendkívüli diverzitást mutat, annak a jele, hogy a 
világ jelenségeinek értékelésében nem az érzékelés, hanem az értelmezés játssza az elsődleges szerepet. Az értelmezésre törekvés az emberi fajra jellemző általános beállítódás. Az értelmezés mint ontológiai adottság az érzékelést is más megvilágításba helyezi. Az érzékelés nem pusztán biológiailag meghatározott sajátosság, amely megmarad a közvetlen benyomások szintjén, hanem kulturálisan meghatározott tevékenység, amely elözetesen kódolt értelmezési stratégiákat felhasználva tereli az egyént fokozatosan a jelentés felé. Az érzéki tapasztalat tehát már a jelentés megszületése előtt magában hordozza a jelentés magját és csak bizonyos interpretációk megszületését teszi lehetővé. A jelentés sohasem esetleges következménye az érzékelésben adott tapasztalásnak, hanem az egyéni életvilág összefüggéseiből kifejlő tartalom. Az értelmezés tehát az érzékelésben predesztinált jelentés lépésről lépésre történő kibontása. Az érzékelés kizárólagos szerepét hangsúlyozó empirizmus ezért valójában eltorzítja a valóságot, miközben megfosztja az egyént ökológiai és szociokulturális dimenzióitól.

Hume a színárnyalatok példáján keresztül a képzelőerő szerepét bizonyítva arra a következtetésre jut, hogy amennyiben az elme a saját forrásaiból képes egy korábban soha nem látott árnyalatot azonosítani, akkor nem lehet teljesen tabula rasa (1896:9-10). Az érzékelés dilemmája különösen szemléletesen mutatkozik meg a reprezentáció problematikája kapcsán. Mitchell szerint az a reprezentációs modell, amely hasonlóságot posztulál az elmében létre jövő képek és a világ jelenségei között, kérdéses. Ez a világnézet ugyanis az érzéki tapasztalatot teszi meg minden tudás alapjának. A képek által hordozott jelentés azonban túlmutat a puszta érzékelés aktusán. A képek bár látszólag egyetemes alappal rendelkeznek, kialakulásukban, utóéletükben többféle hatóerő is szerepet játszik. A „kép” egyfelől az emberi értelem terméke, amelyben gondolataink, hagyományaink tükröződnek. Az általa képviselt jelentés ugyanakkor olyan társadalmi viták, olyan társadalmi egyezségek lenyomata, amelyek célja a konszenzuális valóság megerősítése. A „képek” jelentése tehát nem hozható közvetlen összefüggésbe az általuk ábrázolt dolgok fizikai valójával, értékelésükben pedig a nyelvi tradíció, az ábrázolásról szóló diskurzus évszázados hagyománya is döntő szerepet játszik. A képek valójában szimbolikus struktúrák, amelyek a fordítás szabályrendszerének engedelmeskedve a társadalmi megértést mozdítják elő (1984:509-13).
Az érzéki tapasztalat státusza más szerzők szerint is problematikus. Hallowell vitatja a percepciónak a jelentéselőállításban betöltött elsődleges szerepét. Meglátása, hogy a kulturális jellegzetességek kialakulásában az öntudat, az önreflexióra való képesség a meghatározó. Az érzékelés által közvetített kép nem az objektív világ pontos lenyomata. Ennek oka, hogy az a pszichológiai mező, amelyen belül az emberi viselkedés megvalósul, kulturálisan meghatározott (1955:84). Az emberi öntudat egyik következménye, hogy az ember reflexió tárgyává tette önmagát és az őt körülvevő környezetet is. Ez a megismerési folyamat és az eredményeként létrejött fogalmi rendszer a kulturális örökség szerves részét alkotják. A kultúra ennek értelmében olyan kidolgozott jelentésrendszer, amely az általa müködtetett adaptációs rendszeren keresztül az egyénnek önmagához és az őt körülvevő univerzumhoz füződő viszonyát értelemmel ruházza fel (1955:76).

Ha a valóság ábrázolásának egyedüli kritériuma a percepció lenne, akkor nem lennének spirituális tartalmak, értelmezési stratégiák, mítoszok, rítusok a Földön és nem mutatkoznának eltérések sem az értelmezésben. Márpedig a világ jelenségeinek értelmezése magas fokú kulturális diverzitást mutat. Dilthey (1990) a jelentés történeti és pszichológiai meghatározottságát hangsúlyozza. A jelentésalkotás döntő mozzanata meglátása szerint az élményben adott jelentés, amely a múlt eseményeinek szubjektív megidézése, megélése által ragadható meg leginkább. A megélés egyfajta retrospektív alkotófolyamat, amely az egyéni történet alakulását követve az életút töredékeit kontinuitássá szervezi. A megfigyelés, a közvetlen érzéki tapasztalaton nyugvó vizsgálódás ezzel szemben szétrombolja a megélést, ugyanis tárgyilagosan rögzíti a mozzanatot. Az életút valójában egymással összefüggésben álló élményekből építkezik, és a tudat egységének köszönhetően szerveződik koherens egésszé. Az önéletrajz ezért az élet megértésének legtökéletesebb formája, amelyen belül mindig az egyén és a történelem szempontjából meghatározó jelentőségü mozzanatok kerülnek kiemelésre, a többi pedig feledésbe merül.

A rendezettség, a szabályszerűség iránti fogékonyság szintén a hermeneutikai vizsgálódás egyik meghatározó aspektusa. Bár a konkrét rendezőelvek azonosításának képessége tanulási folyamat eredménye, a rendezettség iránti érzékenység mint kulturális állandó azonban általános emberi sajátosság. Befolyásolhatja az érzékelés és a jelentéselöállitás folyamatát, és kiindulópontja lehet olyan általános 
érvényű szabályozóelvek megfogalmazódásának is, mint amilyenek a társadalom életét meghatározó normák és szankciók. A rendezettség iránti vágy a megfigyelő általános beállítódásának a következménye. A megfigyelő egyik sajátossága ugyanis, hogy konstans elemek után kutat az érzéki tapasztalat szakadatlanul változó közegében, miközben folyamatosan halad az őt körülvevő környezetben. Mivel ezek az állandók tartalmazzák a környezeti jelenségek értelmezéséhez szükséges valamennyi információt, ezért az érzékelés valójában ezen állandók kinyerésére irányuló tevékenység. A megfigyelőnek nincs szüksége arra, hogy az érzékelésben adott tapasztalatot előzetes minták alapján mentálisan újraalkossa, ha az a maga közvetlenségében is hozzáférhető. A jelentés tehát nem a tárgyakhoz mesterségesen hozzárendelt tartalom, ahogyan azt a kognitív tudomány láttatja. A tárgyi környezet a mindennapi tevékenységek mintázatába való beépülése által nyeri el értelmét (Ingold 2000:166-168).

A spirituális tapasztalat szintén egy olyan szegmense az érzékelésnek, amely túllép a közvetlen tapasztalás érzéki bizonyosságán és adott esetben felül is írhatja a megfigyelés szolgáltatta benyomások általános jelentését. A víziók, látomások értelmezése, az értelmezés eredményeként előálló jelentés életútra gyakorolt hatása, életút-szervező ereje különösen fontos szerepet kap az urbánus sámánság rituális gyakorlatai során. Hogyan kapcsolódnak azonban a rítusok közben felderengő víziók, képek a valósághoz? Mi a közös vonás bennük és a valóságban is fellelhető másuk között? Hogyan írható le az érzéki és a spirituális tapasztalat közötti viszony? Egy interjúalanyom a következő látomásszerü élményről számolt be egy dobkör szertartást követően:

Kedves farkasom beköszönt. Ott még valamit csinálni kell. Valamikor ki kell vinni a szabadba. Olyan erő lakozik benne, olyan dominancia kezd mutatkozik benne, hogy ezt ki kell vinni és hasonló közegben meg kell mutatni neki, hogy mi van, mert nagyon bezárva érzi magát. Megmutatkozott egy bölény, ami nekem egy nagyon jó jel. [...] Láttam egy fényoszlopot, aminek a tetején egy szarvas, aranyszarvas motívum volt. És utána kicsit az ősök közé ülhettem a tűzhöz és ez egy nagyon nagy megtiszteltetés volt. Köszönöm nekik, köszönöm a helynek, köszönöm mindannyitoknak.

A spirituális élmény által közvetített tapasztalat nem minden esetben verbális természetű abban az értelemben, hogy az érzékelés tárgya nyelvi eszközökkel egyértelmüen megragadható lenne, hogy a jelölő és a jelölt közötti kapcsolat mindenki számára pontosan beazonosítható lenne. Az értelmezési gyakorlat sem mindig textuális természetű abban az értelemben, hogy a jelentés forrása írásos alapokon, például egy szótárban rögzített szókészlet jelentésvariációin, nyugodna. A spirituális tapasztalatban adott jelentés, különösen a sámánság hagyományát követők körében, közösségi gyakorlatokba ágyazott jelentés, amely kitüntetett minőségek mentén mozog. Az értelmezés eredményeként megszülető tudás nem a priori ismeretek, az elmébe mintegy „beégetett” sémák önigazolási folyamatának eredménye, ahogyan az a racionalizmus világlátásában tükröződik, sem pedig az érzéki tapasztalat eredményeként megszülető ismeret, ahogyan azt az empirizmus követői elvárnák, hanem a környezeti kényszerfeltételekkel való szakadatlan interakció közösségi létbe ágyazott egyéni tapasztalata, és az így megszerzett tapasztalatoknak a szakadatlan újraolvasása, frissítése.

\section{A fordításról}

Az értelmezés, és az értelmezés eredményeként megszülető jelentés, mind a kulturális relativizmus, mind pedig a racionalizmus egyik központi kérdése. A fordítási gyakorlat megítélése azonban különböző elbírálás alá esik a két hagyomány követői körében. Míg a racionalista nézőpont szerint a maradéktalan fordításnak nincs semmi akadálya, hisz minden emberi cselekedetet az ész és az igazság általános elve, és az oksági magyarázat bizonyossága vezéreli, addig a kulturális relativizmus ezzel ellentétes álláspontra helyezkedik. Meglátása, hogy a kultúrák egyediek, az általuk képviselt életvilágok pedig annyira eltérőek, hogy gyakorlatilag minden fordítás kudarcra van ítélve.

Davidson meglátása, hogy noha a nyelvek között alapvető eltérés mutatkozhat, ez mégsem olyan mértékű, hogy a fordítási nehézségeket ne lehetne egy közvetítő nyelv segítségével áthidalni. A kulturális relativizmus valójában paradoxont foglal magában. A nézőpontok különbözősége ugyanis csak akkor tartható fenn, ha van egy közös koordinátarendszer, amelyen belül elhelyezhetjük az eltérő világnézeteket (1974:6). Bár a fordítás nem feltétlenül sikeres minden esetben, és előfordulhat, hogy erőfeszítéseink részleges kudarcba fulladnak, a fordítás teljes kudarca azonban szintén paradoxon. Ha 
ugyanis a fordítás kivitelezése lehetetlen lenne, honnan tudhatnánk, hogy a másik nyelv képviselője valóban fordított? A kulturális relativizmus a fogalmi rendszer és az empirikus tartalom dualizmusaként láttatja a világot, érvel Davidson. Meglátása, hogy az életvilágok egymástól elzárt, öntörvényủ rendszerek, amelyeket elsősorban a nyelvi hagyomány tart össze. A nyelv ebben a kontextusban mint mélystruktúra jelenik meg, amely kihatással van az adott kultúra valamennyi szegmensére. A történelmi múltban berögzült nyelvi mintázatok sajátos világlátást eredményeznek, hisz a megismerés elsősorban nyelvi természetű, és a fogalomalkotás folyamata sem választható el az adott nyelv nyelvtani adottságaitól. A fogalmi rendszerek különbözősége tehát előfeltétele a fordítás kudarcának. Davidson szerint felettébb problematikus, ahogyan a kulturális relativizmus a nyelv és az empirikus tapasztalat közötti kapcsolatot láttatja. A kulturális relativizmus olvasatában úgy tủnik, mintha különböző valóságok, alternatív világok léteznének az egymástól gyökeresen eltérő nyelvtani, illetve klasszifikációs rendszerek egyediségéből adódóan. Davidson szerint ezzel szemben legfeljebb egy világról beszélhetünk. Minden nyelv alapvető sajátossága ugyanis, hogy miközben az általa elrendezett valóság alkotóelemeinek egyedi jelleget kölcsönöz, gyakorlatilag ugyanazt a tárgyi környezetet foglalja rendszerbe. A különböző nyelvek mélyén meghúzódó szabályrendszernek, és a tapasztalati valóságot egésszé szervező alapelveknek ezért hasonlóaknak kell lenniük. Amikor az érzéki tapasztalatról beszélünk, akkor pusztán a tapasztalat forrásának jellegéről beszélünk. A fordítás sikerességét azonban nem a külső valóságból érkező impressziók, hanem a beszélő által vallott hitek, meggyőződések határozzák meg. Davidson meglátása, hogy az igazság közvetlenül adott a kijelentésben, mintegy megelőzi a jelentést. Semmilyen körülmény sem képes ugyanis egy mondatot, vagy kijelentést igazsággal felruházni, csakis az a hit, amelyet a hallgató a beszélő által elmondottaknak kölcsönöz. Mivel a beszélő mondandóját képtelenség értelmezni anélkül, hogy ne tudnánk, miben hisz, ugyanakkor ez a tudás csak a fordítás képessége által válik elérhetővé, ezért az egyetlen lehetséges kiindulópont az, ha a beszélő által tett kijelentések általános igazságtartalmából és a világnézetek közötti harmóniából indulunk ki (1974:14-18).

Ha azonban a jelentés mindenki számára adott, akkor miért mutatkozik eltérés ugyanannak a jelenségnek az értelmezése között már egy adott kultú- rán belül is? Hogyan lehetséges az, hogy a félreértés veszélye folyamatosan beárnyékolja a fordítás sikerességét? A valóságban gyakran még a közös nyelv használata sem mindig biztosítja a megértést és már az elemi percepció szintjén is különbségek mutatkozhatnak. Davidson mintha azt sugallná, hogy mivel létezik teljes megértés, mivel mindent a racionalitás egyetemes eszméje hat át, ezért a különböző életvilágok, fogalmi rendszerek által képviselt olvasatoknak nincs létjogosultsága. Elmélete kizárja a kultúrák sokszínűségét. Ami érdekli, az a szövegnek a szociokulturális valóságtól megfosztott változata. Egy olyan szövegé, amely mentes minden világnézeti eltérésből adódó másodlagos tartalomtól. Valamely abszolútnak vélt olvasat egyoldalú kiemelése azonban könnyen eltorzíthatja a valóságot, figyelmeztet bennünket Carr (1993) a történelmi események vizsgálata kapcsán. Meglátása, hogy az objektív tény gondolata, amely a 19. századi történetírás egyik legterhesebb öröksége, ellentmondást foglal magában. A tények ugyanis csak akkor nyerik el értelmüket, ha előzetesen feldolgozzák őket. Carr óva int a tények fetisizálásától és az értelmezés fontosságát hangsúlyozza. Az értelmezés kritériuma véleménye szerint a vizsgált korszakban élt emberek gondolkodásmódjával való azonosulás és annak tudatosítása, hogy a múlt folyamatait a jelen szemüvegén át szemléljük.

Whorf (1956) bírálja a racionalista álláspontot. Meglátása szerint téves az a nézet, amely szerint a gondolkodás kizárólag a logika általános érvényü törvényszerűségeinek rendelődik alá, és független a nyelvtől. Valójában a megértés az élet minden területén a nyelvi folyamatok függvényében alakul. A nyelvi jelenségek mögött mélyen gyökerező klaszszifikációs rendszerek húzódnak meg, sajátos világlátást eredményezve. A klasszifikációs rendszerek alapját olyan, a távoli múltban keletkezett nyelvi mintázatok képezik, amelyek csak az adott nyelvi közösség számára érthetőek, és elérhetőek. Ezek a mélystruktúrák teszik lehetővé az egyének közötti egyetértés kialakulását. Valamely idegen nyelv ismerete ezért önmagában még nem elégséges feltétele a megértésnek. A nyelvtani rendszereknek a kultúrára gyakorolt hatását Whorf a hopi indiánok időszemléletén keresztül szemlélteti. A hopi kultúra nélkülözi a dimenziók, a különböző idősíkok használatát. A hopik egyfajta időtlenségben élnek múlt, jelen és jövő nélkül. Az időszemlélet kultúraszervező potenciálja helyett sokkal inkább az eseményeknek a beszélő személyével kapcsolatos aspektusai kerülnek előtérbe. Ennek tükrében egy állítás lehet egy- 
szerü beszámoló, kifejezhet közelgő eseményekkel kapcsolatos várakozásokat, illetve általános érvényü törvényszerűségeket. A dimenziótlanság következtében a napok nem vesznek fel többes számot. Az a kijelentés, hogy „öt napot maradtam”, értelmezhetetlen a hopik számára. Helyette az „ötödik napon távoztam" az elfogadott.

A kulturális relativizmus szerint a kultúrák olyan egymástól elzárt világok, amelyek között rendkívül korlátozott, ha ugyan nem teljesen kizárt, a jelentésáramlás. Whorf a fordítás teljes kudarcáról beszél, miközben a kultúrák közötti kapcsolatháló az élet szinte valamennyi területét átszövi. Kereskedelmi és házassági kapcsolatok köttetnek egymással, a különböző társadalmak képviselői tanulmányozzák egymás nyelvét, csodálják egymás művészetét, baráti kapcsolatok sokaságát létesítve a kulturális érintkezések során. Ez nem jelenti természetesen azt, hogy a történelem viharai során ne tüntek volna el teljes kultúrák, gondolkodásrendszerek, ne merültek volna feledésbe jelentések, értelmezési módok, vagy hogy ne kényszerülnénk gyakran spekulációra az értelmezés során a források töredezettsége, hiányos nyelvi ismereteink, vagy az adott kultúrában való tájékozatlanságunk miatt. Ugyanakkor a fordítás korántsem lehetetlen vállalkozás. Bár kiindulópontja mindig az idegen szociokulturális valóság, a jelentés a fordítást végző egyén saját életvilága tükrében megmutatkozó tartalom. Egy cigánysoron élő munkanélküli Shakespeareolvasata ezért ugyanolyan helytálló, mint az angol színházi rendező „fordítása”. Az abszolút, a hiteles fordítás hermeneutikai paradoxon. Csak közelítő értelmezésekről beszélhetünk. A fordító maga is társadalmi lény, aki - egyfajta örökségként - magával viszi az idegen szociokulturális élethelyzetbe saját tudását, előzetes ismereteit, értékeit. A megismerési folyamat ezért mindig az egyéni szubjektivitásnak rendelődik alá, amely kétségeket ébreszt egy egyedi, kizárólagos érvénnyel bíró olvasat megvalósíthatóságával szemben. A kultúrák határai ugyanakkor porózusak. A jelentésáramlás töretlen az életvilágok között, szüntelenül átjárva a mindennapok kommunikációs helyzeteit, legyen szó a tapasztalásnak a saját nyelvi közösségen belül, vagy akár interkulturális szinten megvalósuló formáiról. A kulturális relativizmus ellen szól az a jelenség is, hogy számos nyelv, mint például az arab, megengedő a különféle jelentésárnyalatokkal, jelentésvariációkkal szemben. Az arab nyelvben szinonimák egész sorát hallhatjuk, miközben egy szónok beszédét hallgatjuk. Ha egy nyelv ennyire tág teret enged a jelentésvariá- cióknak, akkor egy lehetséges fordítás maga is könynyebben beleesik a szórásba. További körülmény, hogy bár a megismerési folyamat egyenetlenségeket mutat, az érzékelés ökológiai beágyazottsága mégis olyan közös alapot teremt, amely általános feltételként mindenki számára hozzáférhető. Sikeres fordítás ugyanakkor kizárólag a vizsgált szociokulturális valóság kihívásaihoz igazodva jöhet létre.

A Whorf által felvázolt nyelvi mélystruktúrák merevsége, determinisztikus adottsága, generációk sokaságán átívelő hatása a hagyományok öröklődésének hajlíthatatlanságát idézi. A hagyományoknak a tudásátadásban és a jelentésképződés folyamatában betöltött szerepe azonban nagyon is kérdéses. Tim Ingold meglátása, hogy a hagyomány nem más, mint holt anyag, az információ egy formája, amely nem azonos a tudással. A jártasság megszerzésének a folyamatát elemezve arra a felismerésre jut, hogy a személyes identitás, valamint az egyén karaktervonásainak összessége a társadalmi kapcsolatok területén végbement érési folyamat eredménye, nem pedig átörökítés útján megszerzett bizonyosság, amelyre az egyén még azelőtt tesz szert, mielőtt bárkivel is kapcsolatba lépett volna. Az átörökített hagyományok valójában nem játszanak szerepet az egyéni világkép kialakításában és sokkal értelmesebbé sem válunk felhalmozásuk által. Tudásra csak olyan képességek elsajátítása révén tehetünk szert, mint amilyen a jártasság. A jártasság a jelentés megértésére való képesség a környezetünkbe való közvetlen érzéki alámerülés által. Erre a képességre kizárólag a dolgok bemutatásán keresztül tehetünk szert. A környezetünkben rejlő jelentés tehát nem készen kapott kulcsok, értelmezési módok segítségével megszülető olvasat, hanem hosszas feltárás eredményeként kialakuló tapasztalás, amely az egyén tevékeny részvétele mellett valósul meg (2000:21-22). A jelentésnek nincsenek tehát átfogó, minden szociokulturális élethelyzetre egyaránt kiterjeszthető változatai. A jelentéselőállítás szituatív jellegű, az értelmezés pedig az adott találkozás pillanatába sűrűsödik, amelyet egy következő élethelyzet felülírhat. Az így létrejövő jelentés viszonylagos, érvényességi köre pedig alig lép túl az adott szociokulturális helyzet határain. Mindezek a körülmények cselekvő individuumot feltételeznek, aki nem passzív befogadója a történelem által a múltból átörökített jelentéseknek, hanem annak tevékeny újraolvasója, gyakran újraalkotója.

A kultúrák közötti párbeszéd során nem az a kérdés, hogyan vezethet a fordítás kudarchoz, hanem az, milyen feltételeknek kell teljesülniük ahhoz, hogy létrejöhessen a minél teljesebb megértés. 
Mivel a fordítás eredményeként megszülető jelentés a kultúrák közötti távolság és az életvilágok egyedisége következtében sohasem lehet abszolút, ezért rossz fordítás sem lehetséges. Az olvasatoknak csak hierarchiája van. A jelentés ebben az értelemben tehát kulturális változó, amelynek státusza a fordítást végző személy függvényében alakul. A skála két végpontját az idegen szubjektivitás fordításából adódó jelentés és a saját kultúráját értelmező bennszülött olvasata jelölik ki. A fordítást végző személy hatalmi pozíciója a jelentéseloóllítás folyamatának meghatározó része. Minden idegen jelentéssel szemben tett engedmény ugyanis hatalomvesztést von maga után, amely saját életvilágunk integritását veszélyezteti. A mindenható értelem fennhatósága alá vont interpretáció ezért nem más, mint intézményesített eröszak, a felvilágosodás korának abszolutista öröksége, amely a tudás területeinek szüntelen kisajátítására törekszik. Ebből adódóan az általa szolgáltatott fordítás sem lehet más, csak torz beszámoló. A fordítás sikerességének záloga az idegen életmódba való alámerülés, az adott kultúrára jellemző sajátos gondolkodásmóddal való azonosulás, és a saját kultúra intézményi struktúrájából adódó ellenállás leküzdése. Bár fordítási hibák mindig adódhatnak, a megoldás azonban nem az, hogy a fordítás során engedményeket teszünk, és figyelmen kívül hagyjuk a társadalmi kontextust. A fordítás koherenciáját kizárólag a vizsgált kultúra kozmológiáján és szókészletén belül maradva lehet megvalósítani (Asad 1986:148-159). $\mathrm{Az}$ értelmezési folyamat ugyanakkor paradoxont foglal magában. Miközben az abszolút jelentés, a helyes értelmezés után kutatunk, olvasatok sokféleségét hozzuk létre. A hiteles jelentés azonban mindig gyakorlati közegbe ágyazott, az egyéni életvilág, az egyéni szociokulturális valóság szintjén megmutatkozó tartalom. Az értelmezés eredményeként előálló jelentés további aspektusa az egyén identitáspolitikai törekvéseire gyakorolt hatása. A folyamat meghatározó mozzanata az elfogadás: az a körülmény, hogy mennyire tudunk az idegen kultúra világképével, értékrendjével azonosulni, valamint az integráció: az a képesség, hogyan tudjuk az újonnan megszerzett ismeretek tükrében saját életvilágunkat még koherensebbé tenni.

\section{Az értelmezés új dimenziói egy kutatás tükrében - az ökológiai értelmezés}

Mind Davidson analitikus filozófiája, mind pedig Whorf kulturális relativizmusa alapvetően a nyelvnek az értelmezésben betöltött szerepét vizsgálja, ahogy az a verbális kommunikáció szintjén megmutatkozik. Mindketten a szavakra, a mondatokra, a kimondott, vagy leírt dolgokra koncentrálnak, megfeledkezve a kultúra rejtett, alapvetően nonverbális természetű dimenzióiról, mint amilyenek a spirituális dimenzió felöl érkező tartalmak különféle álmok, víziók, látomások formájában, a környezeti kényszerfeltételek rejtett hatóerőinek ökológiai szinten megmutatkozó ereje, a rendezettség, a szabályszerűség iránti fogékonyság, az idegennel való találkozás pillanatába sűrűsödő bizonytalanság, a szocializáció eredményeként kialakuló viselkedésmódok egyénre gyakorolt hatása, a gyakorlati tevékenységekben való elmélyülés során szerzett tapasztalatok, vagy éppen az individuum szavakba nem mindig önthető belső történései. $\mathrm{Az}$ individuum nem egymástól elválasztott alkotóelemek összetett egysége, mint amilyen a test, az értelem, vagy a kultúra, hanem egy olyan kreatív növekedés egyedülálló színtere, amely kapcsolatrendszerek töretlenül kiteljesedő hálózatán keresztül realizálja önmagát, Tim Ingold gondolataival élve (2000:4).

Meglátásom, hogy az ökológiai beágyazottság meghatározó jelentőséggel bír az érzékelés és az egyéni interpretáció eredményeként megszülető jelentés szempontjából. Ökológiai beágyazottság alatt itt az egyéni mozgástér által behatárolt legtágabb teret értem, amely magában foglalja mind a természeti, mind pedig a szociokulturális valóság adta lehetőségeket. Az egyén nem a környezeti és társadalmi kényszerfeltételektől függetlenül létező élőlény, hanem attól elválaszthatatlan entitás, aki a környezetével szemben kialakított érzékenysége által tesz szert különböző ismeretekre. Gibson (1986) meglátásait követve úgy vélem, hogy a lehetőségek konstans információként vannak jelen az érzékelésben. A megfigyelőnek ezért nincs szüksége előzetes tapasztalatra ahhoz, hogy környezetével interakcióba lépjen, vagy hogy a külső valóságot előzetes minták alapján újraalkossa, ahogy azt a kognitív tudomány feltételezi.

Az ökológiai térben az érzékelés kiindulópontja a megfigyelési pont. A megfigyelési pont a természeti, vagy a szociokulturális közegben elfoglalt hely, nem pedig a geometriai térben elfoglalt absztrakt pozíció, amely bár vizualizálható, azonban nem látható. A megfigyelési pont jellege az optikai rendezettség elvével írható le. Amikor a megfigyelő elfoglalja megfigyelési pontját, az optikai rendezettség nemcsak az egyént övező térről, hanem magáról 
a megfigyelő személyéről is információkat közvetít. Másik fontos jellemzője az ökológiai térnek, hogy a megfigyelö által felvett megfigyelési pont sohasem állandó. A megfigyelő ugyanis folyamatos mozgásban van környezetében, amely interakciók, értelmezési helyzetek végeláthatatlan sorozatát eredményezi. A mozgás természetéből adódóan két individuum lehet ugyanazon a helyen, de eltérő időben, illetve ugyanaz a hely eltérő arcát mutathatja más-más időpontokban. Képzeljünk el egy kertet gyümölcsfákkal télen és nyáron. Bár vizsgálatunk tárgya és megfigyelési pontunk is ugyanaz, az érzékelésből adódó értelmezés mégis eltérő jelentést eredményezhet. Amennyiben a megfigyelők különböző szociokulturális valóságból érkeznek, az értelmezésben mutatkozó jelentés még nagyobb eltéréseket mutathat. Az absztrakt idő szintén értelmetlen az ökológiai térben zajló események szempontjából. Nem az időt, hanem a folyamatokat, a változásokat érzékeljük. Az ökológiai térben zajló folyamatok ugyanakkor kettős arcot mutatnak: egyszerre jellemzi őket a változás és az állandóság. Az állandóság ugyan a változások felett helyezkedik el, mégis relatív: a változás folyamata ugyanúgy átjárja, mint a kultúra időben kevésbé rögzített, az elmúlás folyamatainak jobban kiszolgáltatott alkotóelemeit.

A megfigyelő által képviselt szociokulturális valóság és a vizsgálat tárgyát képező idegen kultúra az ökológiai térbe foglalt percepció szintjén tehát közös metszetben találkoznak. Ez a metszet azonban nem egy zárt halmaz, amelynek elemei pontosan beazonosíthatóak, meghatározhatóak lennének. Sokkal inkább egy olyan nyílt végü tartomány, amelyen belül a lehetőségek bár konstans információként jelen vannak az érzékelésben, megítélésük azonban az egyes kultúrák szintjén eltérést mutat. Lehet, hogy egy adott kultúra képviselője érzékeli a jelenséget, de nem tulajdonít neki semmilyen jelentőséget. Az is lehet, hogy bár fontosnak tartja, de egy teljesen más aspektusát emeli ki, esetleg olyan jelentéssel ruházza fel, amely teljesen idegen a másik kultúra szellemi hagyományától. Meglátásom, hogy az értelmezés nem egyszerüen az érzéki tapasztalatban adott jelenségeknek az adott kultúra hagyományrendszerétől független olvasata, sem pedig valamilyen általános eszme mentén megfogalmazódó interpretáció, amely mentes minden szubjektivitástól, hanem olyan értékalapú vizsgálódás, amelyben mindig az egyéni világnézetre, az egyéni szociokulturális valóságra reflektáló jelentés tükröződik, amelyet a percepció általános ökológiai adottsága foglal keretbe. Az értelmezés tehát mindig valamilyen értékrend, és ezáltal a saját kultúra felé elkötelezett. Az értékrend ebben az olvasatban a jelentés egyik lényegi összetevője, amelyet az adott szociokulturális valóság alkotóelemei közötti dialogicitás, az értékek pozícionált jelentéséből adódó dinamizmus, valamint az egyéni interpretáció kitüntetett szerepe jellemez. Az egyén mindig személyes élethelyzetére reflektálva határozza meg értékeit és alakítja ki értékrendjét azokból az értékekből, amelyek az életút adott pontján kiemelt jelentőségre tesznek szert. Az értékrend tehát vagy már meglévő értékek újraolvasása során keletkező értékvariációk, vagy pedig az új szociokulturális helyzetre reflektálva megszülető új értékek gyüjteménye (Gyökér 2016:85-86). Mivel maguk az értékek is a szociokulturális valóság részét képezik, ezért a kultúra többi aspektusához hasonlóan, szintén értelmezés tárgyává válhatnak.

\section{Esettanulmány}

Kutatásom során a sámánság városi létbe kényszerülő formáját vizsgáltam egy magát urbánus sámánoknak valló közösség, hivatalos nevén Concordantia Carpatiensis, mindennapjait nyomon követve. A 2009-ben alakult közösség legföbb célkitűzésének a Kárpát-medence tudathálózatának harmonizálását tekinti, amelyet ősi sámáni technikák - révülések, látomások - segítségével igyekszik megvalósítani. Bár a közösség összejöveteleire leginkább Budapesten, illetve más városok urbánus közegében, kerül sor, a tagok igyekeznek minél többször találkozni a természetben is. Spirituális központjuk is a Pilishez tartozó Látókőn található.

Az urbánus sámánság meggyőződése, hogy a természet, mint közeg, csupán másodlagos szereppel bír az összejövetelek során átélt spirituális tapasztalat szempontjából. A találkozások célja ugyanis, hogy a „kapcsolódást”, az egymáshoz és a szellemvilághoz közeledést elősegítse, függetlenül attól, hogy a sámáni technikákat természetes, vagy mesterséges közegben gyakorolják a résztvevők. A közösség másik sajátos vonása, hogy a tagok felfogásmódjában a sámánság női ága játssza a meghatározó szerepet. A korábban fóként férfiak által müvelt gyakorlatok a közösségen belül új dimenziót nyernek: a női szerep újragondolása, a férfi és nő közötti harmonikus viszony megteremtése, a közösségiség újrafelfedezése a legfőbb mozgatóerők. A női minőség erőteljesebb jelenléte azonban nem jelent kirekesztést: a közösségnek férfi tagjai éppúgy vannak, akárcsak nők. 
A hagyományos sámánságon belül a sámán kiválasztásának több módja is lehetséges. A hivatás átadása lehet örökletes, mint például a szibériai szamojédoknál, ahol a jövendő sámánt bizonyos külső jegyek alapján már születésekor azonosítják, illetve beszélhetünk spontán elhivatásról is, mint például a jakutoknál, ahol a sámánságra rendeltetett jelölt váratlanul jelentkező „viselkedészavarokkal” adja környezete tudtára a benne rejtőzködő képességeket. Bárhogyan is legyen, személyét csak akkor ismerik el sámánnak, miután átesik bizonyos beavatási szertartásokon (Eliade 2005:19-37). Az urbánus sámánság ezzel szemben jóval megengedőbb a sámán személyével kapcsolatban. Meglátása, hogy mindenkiben ott rejlik a sámáni tehetség. Hogy kibontakozik-e, az egyéni elhatározás függvénye:

Amit én tartok, hogy a sámánság, az a tapasztalás útja. Valójában itt nem arról van szó, hogy a sámán az egy kiemelt személy, akitől várnunk kell bármit is, hanem nekünk is lehetöségünk van arra, hogy kinyissuk ezeket a belső csatornáinkat, a belső érzékelésünket és ugyanúgy tudunk kapcsolódni, ahogy egy sámán. A különbség az annyi, hogy megvalósultabbak, tisztábbak a csatornák, tisztább a belső látás. Tehát könnyebben át tud hozni akár információkat, akár erőket abból a szellemi térből, ami körbevesz bennünket. De valójában én azt tartom, hogy erre bárki képes lehet.

Az értelmezés mindig a jelenből indul ki, még akkor is, ha a múlt tartalmait vizsgálja. A múlt építészeti, irodalmi alkotásai, filozófiai, esztétikai nézetei, társadalmi szokásai olyan keretrendszert alkotnak, amelyet a jelen értelmezési stratégiai ruháznak fel tartalommal. Az eredeti üzenet mindig nehezen hozzáférhető, ha éppen el nem veszett teljesen. Mivel az egyéni személyiségjegyekből adódó motivációk eredete a szociokulturális valóság spektrumának összetettségéből adódóan felfejthetetlen, vagy legalábbis nehezen hozzáférhető, ezért a jelentés gyakorlati működése az, ami meghatározó. Ebben a folyamatban az adott szociokulturális helyzet érzékelése és értékelése mint kiindulópont döntő szerepet játszik.

Bár az érzékelésben adott tapasztalat mindenki számára egységesen hozzáférhető, a jelentés sohasem rögzített adottság, hanem az érzékelés, az értékrend és az értelmezési módok, interpretációs technikák metszetében létrejövő szubjektív tapasztalat, amely egy adott társadalmi közegbe illeszke- dik. Hogy az egyes kultúrák az érzéki tapasztalatot milyen értékrend, illetve milyen értelmezési stratégiák mentén foglalják egységes keretbe, eltéréseket mutat. Az értelmezés maga ugyanakkor folyamatjelleget tükröz. Helyesebb ezért meglátásom szerint jelentéselőállításról beszélnünk. A sámánságon belül az értelmezés hosszú távú tapasztalás során kialakuló bizonyosság. Az értelmezési folyamat akár több évet is átölelhet. A jelentés spontán élethelyzetekben tárja fel magát. A látomások során megmutatkozó tartalmak, impressziók mindig csak utólag nyerik el jelentésüket, de utóéletük ezzel nem zárul le, hanem folyamatosan tovább gazdagodik:

Mindennek lehet üzenete, és általában van is. És nagyon lassan bontakoznak ezek ki. Sokszor van az, hogy eltelt egy-másfél év és most értek meg folyamatokat, amik akkor történtek és mit szimbolizáltak. [...] Tényleg ilyen nagyon lassított és hosszított hatása van.

$\mathrm{Az}$ értelmezési folyamat alapvető jellemzője a gyakorlati aspektus kiemelt szerepe. A spirituális és az anyagi világ az értelmezés közös metszetében találkoznak, amelyet a szubjektív tapasztalás foglal keretbe. Az anyagi világ, a bennünket körülvevő szociokulturális környezet alkotóelemei, de a társas kapcsolatok is spirituális jelentéssel telítődnek és az értelmezési tartomány részévé válnak. A spirituális tapasztalás és értelmezés képei ugyanakkor „kevert” képek, amelyek eredete nem korlátozódik kizárólag csak a sámánság hagyományos szimbólumvilágára, hanem sokkal átfogóbb kontextusba illeszkedik. Az értelmezés kontextusát az egyéni életvilág személyes tartalmai jelölik ki. Ahogyan az egy interjú-alanyom szemléletes leírásában tükröződik:

Inkább azt érzem, hogy nem én értelmezem ezeket, hanem úgy rendeződik valahogy a tér, a környezet és az emberek, akikkel találkozom, akik elhozzák a kulcsokat, a megoldásokat. Tehát akár egy személlyel való beszélgetés formájában, vagy egy könyvből, egy zenéből, ami így visszareflektál arra a tapasztalásra, amit akkor ott egyszer már megéltem és beindítja az értelmezést. Amikor pont egy olyan helyzetben vagyok, mondjuk megjelenik a Hórusz szeme, amit én emlékszem, hogy láttam a fák között, hogy a nap egy hatalmas szemmé változott. És utána ezekkel így nem dolgoztam, vagy nem foglalkoztam, hanem másfele volt a figyelmem. És amikor ez így előjön valahol, akkor kapsz egy 
üzenetet és utánanézel. [...] És akkor mindig olyan összefüggések oldódnak meg, amire épp szükség van. Én egy ilyen terelést érzek ezáltal.

Az ökológiai beágyazottság rejtett dimenzióinak egyik sajátos megnyilvánulási formája az újjászületés élménye. Az élet rituális megújításának igénye egészen az archaikus kultúrákig visszanyúló gyakorlat (Eliade 1993). A káoszból a kozmoszba való átmenet mint kozmogóniai esemény leképezése az urbánus sámánság rítusaiban azonban új felhangot kap. Míg a természeti népeknél az őseredeti káosz feletti győzelem, tehát a mitikus idő megjelenítése kap kiemelt szerepet, addig az urbánus sámánság szemléletmódjában az idő személyes aspektusa kerül előtérbe. A szubjektív tapasztalás kiemelt jelentőségű az olyan szertartások során, mint amilyen a látomáskeresés. Személyes élményeikről a szertartást követő úgynevezett megosztó kör alkalmával számolnak be a résztvevők. Az archaikus népek időszakos, a naptári év során egyenletesen elosztott szertartásainak rendje szintén átalakul. Az olyan szertartások határa, mint amilyenek a démonűzések, vagy a beavatási szertartások voltak, fellazul, és gyakran több rítus is egyetlen szertartás alkalma köré sűrűsödik. Az ökológiai beágyazottság mármár meseszerüen felfokozott jelenléte különféle természeti motívumok formájában, a szubjektív tapasztalás kiemelt szerepe, valamint különböző rítusok egyetlen szertartásba történő integrációja jól érzékelhető interjúalanyom beszámolójában:

Azt éreztem, hogy ilyen kis mag vagyok, ami áttör a földön ez alatt a négy nap alatt, mert hogy három napig esett az eső és az esőben feküdtem ott kint. És nagyon sok bogár volt és giliszta. És teljesen egy ilyen küzdés volt. De egy gyönyörű küzdés, mert a végére megjelentek aztán a szentjánosbogarak, akik így körüllebegtek, és odajöttek körém. Meg hát amikor felkelt az utolsó napon a nap, az tényleg egy ilyen újjászületés élmény volt. Ahogy kimásztam így abból a bábból, amit ott alkottam magamnak az esőben, a hálózsákban.

A lélekutazás élménye az urbánus sámánságban az úgynevezett mesternövények hatásához köthető. Használatuk a dél-amerikai sámánság hatására épült be a hazai urbánus sámánság rítusai közé, jól példázva a jelentésáramlás globális jellegét. A mesternövényekkel való kapcsolat személyes kapcsolat, amely minőségében leginkább a hagyományos sá- mánság segítőszellemeinek szerepével rokonítható. A mesternövények a tudatosság legmagasabb szintjével rendelkező élőlények, a szellemvilág földi megtestesülései. Segítségükkel megnyílnak a világok közötti kommunikációs csatornák, és elindul egy gyógyító szándékú jelentésáramlás a túlvilág felől világunk felé. A mesternövények elősegítik az egyik legmagasabb szintű tapasztalást: a Földanya rendszerére való rákapcsolódást. Ez a globális szintű eggyé válás gyakori motívuma a beszámolóknak:

Felfedeztem addigra, hogy működik bennem egy ilyen áldozatprogram. És akkor elöször mentem erre a szertartásra úgy, hogy tudtam, hogy mit kérek a növénytől, hogy miben segítsen nekem. És az ez volt, hogy ezt az áldozatprogramot segítsen letenni nekem. És hát segített is. Körülbelül egy hétig a föld felett jártam utána. Olyan élményt kaptam, amit nem nagyon lehet szavakba foglalni. Mindennel egy voltam. Test és anyag nélkül. Nagyon nehéz ezt leírni. De ott megtapasztaltam, hogy minden és mindenki egy. És akkor sikerült is letennem úgy érzem ezt a programot magamról, vagy legalábbis egy jó részét. És sokkal jobban tudtam utána becsülni saját magam. És onnantól kezdve tudtam kiállni magamért. Gyakorlatilag egy hét múlva lehúztam a gyűrűmet és kiszálltam ebből a kapcsolatból, mert rájöttem, hogy ez rombol engem.

Én úgy képzelem el, hogy ezek a növények segítenek kitisztítani azokat a csatornáit az embernek, amik által kapcsolódhat a szellemvilággal. És egyre inkább kitágítják, kitisztítják és egyre tisztább és szélesebb érzékelése lesz tőle az embernek mindenféle tekintetben. Önmagára való rálátásban, másokra való rálátásban. Egyszerűen megmutatnak olyan mintázatokat a világban, meg önmagunkban, amiket utána nem tud semmi elvenni tőled. És persze segítenek olyan gócokat feloldani az emberben, amik gátolhatják őt. Minden növénynek, mindennek a világon van szelleme, tudata és ezek a mesternövények rendelkeznek a legmagasabb tudatossággal és képesek az embert rákapcsolni erre a rendszerre. A Földanya rendszerére.

Bár az urbánus sámánság gyakorlataiban a szubjektumnak jut a kitüntetett szerep, maguk a szertartások ugyanakkor közösségi események, amelyek az egyén társas kötődését, a közösségi lét felértékelődé- 
sét, megerősödését hangsúlyozzák. A perifériák felértékelődése, a lokális kisközösségek újrateremtése iránt mutatkozó egyre fokozódó igény a posztmodern kor talán egyik legfontosabb fejleménye. Csak egy lokális szinten müködő közösség lehet képes ugyanis arra, hogy a közösségi igények mellett az egyéni önkifejezésnek, a személyiség kiteljesedésének is megfelelő terepet biztosítson. A gyakran identitásválságba került, a társadalmi szabályok túlzó kontrollja elől menekülő egyén tudatosan fordul a közösség felé, tudván, hogy határai között ismét otthonra lelhet (Gyökér 2017:82-83). Minden szertartás, legyen az egy dobkör, egy látomáskör, vagy egy izzasztókunyhó építése, közösségi létbe ágyazott cselekedet, amely nemcsak a szubjektum kiteljesedéséről, hanem a közösség önmegerősítéséről is szól. A résztvevőket egyfajta túlvilági kapocs fogja össze, amelyet a spirituális dimenziók kiteljesedésének megnyilvánulási formájaként értelmezhetünk. Az idegenségtapasztalat hordozta félelem elválasztó ereje leomlani látszik. A résztvevők közös spirituális térben egyesülnek:

A segítők azért is vannak jelen, ahogy a naptáncon is, hogy támogassák a résztvevőket, segítsék őket a böjtjükben. Kialakul köztük egy energetikai kapocs. Én bevallom nagyon szkeptikus voltam ezzel kapcsolatban, amikor elöször hallottam, és azt gondoltam, hogy milyen éhes leszek, és milyen szomjas leszek, de annyira éreztem ezt a kapcsolatot köztünk és a segítők között. Nekik az volt a feladatuk, hogy akármikor azt érezték, hogy éhesek, hogy szomjasak, vagy fáznak, akkor kezdjenek el enni, inni, vagy öltözzenek még jobban fel, mert össze vannak kapcsolódva velünk és valamelyikünknek az éhségét, szomjúságát veszik át gyakorlatilag. És csodálatosan működött. Nem kellett azzal foglalkoznom, hogy akár éhséget, vagy szomjúságot érzek. Nagyon szép volt ezt a típusú segítséget, ezt a típusú kapcsolatot megélni.

A világok közötti utazás központi eleme a sámánisztikus hagyománynak. Ez a motívum az urbánus sámánság gyakorlataiban is kitüntetett szereppel bír, dimenziói ugyanakkor kitolódnak a hagyományos felfogáshoz képest. A világok közötti spirituális utazást a szociokulturális tértől való eltávolodás előzi meg, amely a lakóhely urbánus közegétől a természeti környezet felé halad. A kettős utazás jelenségét, valamint a társadalmi miliő negatív hatásainak leküzdésére irányuló erőfeszítést példázza a következő beszámoló:
Nyilván kell idő arra, hogy az ember megérkezzen [a szertartásra], mert az átlagéletből, ahol más tudatállapotban vagyunk, és folyamatosan kifele kell figyelni, körbe vagyunk véve egyfolytában ingerekkel, fényekkel, zajokkal, mobillal, laptoppal. Kell, hogy a lélek is megérkezzen és a szellem is lecsituljon. Nálam ez ilyen egy másfél nap, amikor úgy érzem, hogy bekerültem egy olyan állapotba, ami sokkal nyugodtabb és sokkal tisztább, mint amit a mindennapokban élek meg.

A társadalmi életben bekövetkezett változások a kontextuális értelmezés fontosságára hívják fel a figyelmet. Az urbánus sámánság gondolatvilágának, az általa megszólított problémáknak a határát a posztmodern kor emberének vívódásai jelölik ki, szemben a hagyományos sámánsággal, ahol a sámán elsősorban a közösség anyagi szükségleteinek kielégitése céljából tevékenykedett (Diószegi 1962). Az urbánus sámánság szemléletmódjában a természettel szemben elkövetett „bűnök” kiváltotta bűntudat, a hatalom által működtetett metanarratívák generálta kirekesztettség, a közösség utáni vágy érzése, valamint a megbillent férfi-nő viszony visszaállításának igénye keveredik egymással:

Elfelejtettük, hogy mindennek van lelke, szelleme és gyakorlatilag a szolgálatunkba állítottuk a növényeket, állatokat és teljesen tiszteletlenül bánunk minden egyes létezővel ezen a Földön. Pontosan ez a lényege a sámánságnak, hogy kapcsolódj vissza a természethez, mert az a te otthonod.

Ha az ember tudatosan arra fordítja a szabadidejét, hogy kapcsolódjon a természettel és más hasonló úton járó emberekkel, akkor ezt városban is meg lehet tenni. A legnagyobb gátja az embernek: az önfenntartásért vívott küzdelem. A felsőbb emberi hatalmak pont ezt akarják elvenni az embertől. Hogy üljél a TV előtt, olvasd az újságot, idegeskedj a hülye politikusok miatt. Tehát teljesen elveszik az ember figyelmét, és afelé terelik, hogy a kényelem legyen a legfontosabb.

A világban egy elég nagy elidegenedés zajlik, illetve zajlott az elmúlt évszázadokban, de én látok egy olyan folyamatot, amikor ez elindul visszafelé abba az irányba, hogy újra legyünk közösségben, alkossunk közösséget, legyünk 
úgymond egy lélekcsalád részei a fizikai családunkon túl. Nagyon fontosak az ősök, nagyon fontosak a gyökereink, a hagyatékunk. És ezen túl viszont nagyon fontos az, hogy akik egy közösség részeivé tudnak válni, azok valahol lélekben nagyon mélyen összekapcsolódnak. Tehát ez egy második család a fizikai családon túl.

Hogy hol csúsztak meg a dolgok, azt nehezen tudnám visszakeresni. Már az is egy elcsúszás, hogy férfiak uralják a világot elég régóta. Szóval azt gondolom, hogy a feminizmus az egy teljesen jogos kezdeményezés és mozgalom volt, hiszen a nőt is föl kellett emelni a férfi mellé. Viszont ma már ez egy teljesen elcsúszott dolog. Sajnos túltoltuk ezt a feminizmus dolgot. Ma már elment odáig, hogy legyenek a nők is férfiak. Nem. Nem kell, hogy a nők férfiak legyenek. Kell, hogy legyen egy férfi oldaluk is és arról is tudomással kell bírni. De meg kellene találnunk a helyünket.

A kultúra nem pusztán „öröklött koncepciók szimbolikus formába öntött rendszere” (Geertz 1973:89), hanem szüntelen változásnak és ebből adódóan szakadatlan újraértelmezésnek kitett közeg, amelyet a különböző forrásokból eredő jelentések közötti dialogicitás és az egyéni interpretáció értékorientált folyamata foglalnak keretbe. Ez a körülmény megkérdőjelezi a „hiteles” olvasat fogalmának létjogosultságát. Köpping meglátása, hogy mivel a múltbeli cselekvési formákról nem áll rendelkezésünkre hiteles sablon, ezért az autentikusság fogalma is viszonylagossá válik. Ebben az értelemben a hitelesség kérdése sokkal inkább a résztvevők képzeletében élő eszménykép kritériumaival, mintsem a társadalmi aktus ősképével áll kapcsolatban. Minél közelebb áll tehát egy performatív aktus az eszményképhez, a résztvevők annál autentikusabbnak ítélik meg (Köpping 2004). A hiteles, azaz minden más olvasatot kizáró jelentés gondolata valójában paradoxont foglal magában, hisz a kultúra különböző olvasatok rendkívül sokrétű aggregátuma. A sámánisztikus hagyomány rítusai gyakran restaurált, mesterségesen feltámasztott formái egy letűnt és töredezett múltnak, amelyek új értelmezésre szólítanak fel. Ez a tendencia rendkívül érzékletesen mutatkozik meg a következő beszámolóban, amely a sámánság küldetését a posztmodern kor kihívásaira adott válaszként definiálja:
A sámánság nem feltétlenül a természeti közegről szól. A közegről szól. Tehát a mesterséges közegről éppúgy, mint a természetesről. Tehát az urbánus sámánság jelen pillanatban hatalmas ívvel íródik föl, mert szükség van rá. A városokban éppúgy szükség van rá, mint az őserdőben. Sőt! Fölépítettünk egy fantasztikus civilizációt, amiből gyakorlatilag kilúgoztuk a szellemiséget. Észérvekkel, intellektussal, vallásokkal, az égvilágon mindenfélével. Létrehoztunk egy egyre inkább működésképtelen valamit, amivel az egész emberiségnek a fönnmaradását tesszük kétségessé. Úgyhogy erről van szó igazából.

\section{Összefoglalás}

Írásomban a fordítás hermeneutikai dimenzióit vizsgáltam. Az urbánus sámánság rítusainak bemutatásán keresztül kísérletet tettem egy újfajta megközelítés, az ökológiai interpretáció bemutatására. Kutatásom során abból a feltételezésből indultam ki, hogy a spirituális oldal felől érkező üzenetek jelentésének értelmezése nem egyszerű fordítás, hanem közösségi létbe ágyazott gyakorlatok eredményeként megszülető tartalom, amelynek jelentéstartományát az egyén ökológiai beágyazottsága, az értelmezés nonverbális természetủ aspektusai, valamint az értelmező szubjektum értékrendje határozzák meg. Az így létrejövő jelentés pillanatnyi jelentés, amely az idő előrehaladtával folyamatos változásnak van alávetve. A jelentéselóállítás tehát folyamat-jelleget mutat, amely mindig az életút egy adott pillanatának lenyomatát hordozza magán. Mivel a fordítás az egyéni életvilág tartalmainak függvényében megmutatkozó tartalom, ezért abszolút fordítás nem lehetséges. Hasonlóképp ellentmondásos fogalom a fordítás kudarca is. A fordítást végző személy társadalmi státusza a jelentéselőállítás folyamatának döntő aspektusa. A jelentések hierarchikus rendbe tagozódnak: érvényességi körüket a mindenkori társadalom hatalmi erőviszonyai határozzák meg. 


\section{Felhasznált szakirodalom}

Asad, Talal 1986 The Concept of Cultural Translation in British Social Anthropology. In Writing Culture: The Poetics and Politics of Ethnography, edited by James Clifford and George E. Marcus. Berkeley, University of California Press, 141-165.

Barnes, Barry - Bloor, David 1982 Relativism, Rationalism and the Sociology of Knowledge. In Rationality and Relativism, edited by Martin Hollis and Steven Lukes. Blackwell, Oxford, 21-47.

Boas, Franz 2006 Az összehasonlító módszer korlátai az antropológiában. In Mérföldkövek a kulturális antropológiában, szerk. Paul Bohanann - Mark Glazer. Budapest, Panem, 135-146.

Bourdieu, Pierre 1990 Gazdasági gyakorlat és idő. Az algériai parasztok időkezelési attitűdjei. In Időben élni, szerk. Gellériné Lázár Márta. Budapest, Akadémiai Kiadó, 48-59.

Carr, Edward Hallett 1993 Mi a történelem? Budapest, Századvég Kiadó, 7-53.

Davidson, Donald 1974 On the Very Idea of a Conceptual Scheme. Proceedings and Addresses of the American Philosophical Association 47:520. https://doi.org/10.2307/3129898

Dilthey, Wilhelm 1990 Vázlatok a történeti ész kritikájához. In Filozófiai hermeneutika, szerk. Bacsó Béla. Budapest, ELTE, 61-91.

Diószegi Vilmos 1962 Samanizmus (Online) http://mek.oszk.hu/01600/01639/01639.pdf (2019. január)

Eliade, Mircea 1993 Az idő megújítása. In Az örök visszatérés mitosza avagy a mindenség és a történelem. Budapest, Európa Könyvkiadó, 81-141.

Eliade, Mircea 2005 A samanizmus. Budapest, Osiris Kiadó.

Gibson, James J. 1986 The Ecological Approach to Visual Perception. New York, Psychology Press. Taylor \& Francis Group.

Geertz, Clifford 1973 The Interpretation of Cultures. New York, Basic Books.

Gyökér Róbert 2017 Grundkert. Kisközösség a nagyvárosban. Kultúra és közösség, 8(2):75-99.

Hallowell, A. Irving 1955 Culture and Experience. Philadelphia, University of Pennsylvania Press.

Ingold, Tim 2000 The Perception of the Environment. Essays on livelihood, dwelling and skills. London, Routledge.
Hume, David 1896 A Treatise of Human Nature. (Online) https://people.rit.edu/wlrgsh/ HumeTreatise.pdf (2019. január)

Jávor Kata 1989 A család, a szerepek és az identitás alakulása falus In $A z$ identitás - kettös tükörben, szerk. Váriné Szilágyi Ibolya - Niedermüller Péter. Budapest, Tudományos Ismeretterjesztő Társulat, 141-173.

Köpping, Klaus-Peter 2004 Az etnográfia a hitelesség és a performativitás határmezsgyéjén. In Az Idegen. Variációk Simmeltôl Derridáig, szerk. Biczó Gábor. Debrecen, Csokonai Kiadó, 61-79.

Locke, John 1999 An Essay Concerning Human Understanding. (Online) ftp://ftp.dca.fee. unicamp.br/pub/docs/ia005/humanund.pdf (2019. január)

Mitchell, Thomas 1984 What is an Image? New Literary History 15(3):503-537. https://doi. org/10.2307/468718

Moore, Omar Khayyam 1957 Divination - A new perspective. American Anthropologist 59(1):69-74. https://doi.org/10.1525/ aa.1957.59.1.02a00060

Prior, A. N. 1960 The Runabout Inference-Ticket. Analysis 21(2):38-39. https://doi.org/10.1093/ analys $/ 21.2 .38$

Whorf, Benjamin Lee 1956 Science and Linguistics. In Language, Thought, and Reality, edited by John B. Carroll. Cambridge, The Technology Press of Massachusetts Institute of Technology, 207-220.

Winch, Peter 1964 Understanding a Primitive Society. American Philosophical Quarterly 1(4):307-324.

Winch, Peter 1988 A társadalomtudomány eszméje és viszonya a filozófiához. Akadémiai Kiadó, Budapest. 